\title{
MORPHOLOGICAL FEATURES OF FRUITS OF VARIOUS SPECIES OF CHILLI PEPPERS
}

\author{
Mňahončáková Erika ${ }^{1}$, Valný Patrik ${ }^{2}$, Horčinová Sedláčková Vladimíra ${ }^{* 2}$ \\ ${ }^{1}$ Botanical garden at the Slovak University of Agriculture in Nitra, Slovak Republic \\ ${ }^{2}$ Slovak University of Agriculture, Institute of Biodiversity Conservation and Biosafety, \\ Nitra, Slovak Republic
}

Received: 13. 11. 2020 Revised: 16. 11.2020 Published: 20. 11. 2020

The research focused on Capsicum spp. collection (C. annuum L., C. baccatum L., C. chinense Jacq.) cultivated under green-house conditions and examined in the term of morphological characteristics of quantitative (6) and qualitative (4) traits. Aim of the study was to determine the variability in the morphological fruit characters of 28 cultivars. The results revealed considerable morphological variability between average weight of fruits $(0.32-25.94 \mathrm{~g})$, weight of peduncle $(0.01-0.41 \mathrm{~g})$, weight of exocarp (0.24-24.60 g), weight of seed (0.04-2.14 g), weight of ovary (0.17-4.92 g) and number seeds per fruit (14.2-185.8 pieces). A cluster analysis was carried out, and a dendrogram was established. With quantitative variables, 6 groups were obtained. Correlations between morphological variables were also estimated. There were highly significant differences for most quantitative characters. The study showed that the weight of fruits parameters is correlated with the variables related to the weight of exocarp and weight of ovary. High diversity based on qualitative traits was detected for the shape of fruits, the colour of fruits ect. Obtained results confirmed that chilli peppers are suitable germplasm for their cultivation and distribution as ornamental plants, their potential uses and benefits to mankind cover many areas processing into food and nutrition, cosmetics, plant-based insecticides, pharmaceutical or medicine products.

Keywords: Capsicum spp., fruits, cultivars, morphometric characteristic

\section{Introduction}

Chilli pepper (Capsicum spp.) is a solaneceous plant, whose centre of origin in Middle America and Mexico is centre of genetic diversity and domestication. In the world, several hundred types of peppers are cultivated. The five major cultivated and economically most important species of Capsicum are C. annuum L., C. chinense Jacq., C. frutescens L., now widely cultivated throughout Europe, the southern United States, Africa, India, and China, and C. baccatum L. and C. pubescens Ruiz \& Pav., cultivated predominantly in South America (Basu and De, 2003; Scaldaferro et al., 2018). The genus comprises approximately 42 described

\footnotetext{
*Corresponding author: Vladimíra Horčinová Sedláčková, Slovak University of Agriculture, Institute of Biodiversity Conservation and Biosafety, Nitra, Slovak Republic $\checkmark$ vladimira.sedlackova@uniag.sk
} 
species (Barboza et al., 2019), with wide range of morphological variability, mainly in different shapes, sizes, colours and sensory attributes of its fruits (Nwachukwu et al., 2007; Barbosa et al., 2010; Ballina-Gómez et al., 2013; Wahua et al., 2014; Bicikliski et al., 2018).

Capsicum terminology is very confusing with pepper, chilli, chile, chilli, aji, paprika, and capsicum all used interchangeably to describe the plant (DeWitt and Bosland, 2009). Csillery (2006) indicates that the first component description of Capsicum was given in Hungarian herbal by Dioszegi and Fazekas (1807) cited by Bozokalfa et al., (2009). Chilli pepper is an important agricultural crop, not only because of its economic importance, but also for the nutritional value of its fruits (Aliu et al., 2017), mainly due to the fact that they are an excellent source of natural colours and antioxidant compounds (Rodríguez-Maturino et al., 2011; Medina-Juárez et al., 2012).

The Capsicum genus includes the sweet and hot chilli peppers, which have been popular from ancient times and at present are of great commercial interest, not only for the taste and colour of their fruits (Shaha et al., 2013), but also because of their essential oils and the presence of capsaicin (Pruthi, 2003; Nadi et al., 2020). Capsaicin is the pungent principle of hot chilli peppers, which are commonly used as spices and as medicines (Saleh et al., 2018), mainly applied topically to relieve neuropathic pain and itching (Papoui and Yosipovitch, 2010). The number of studies report that hot pepper seeds are rich in minerals content (Jarret et al., 2013; Zou et al., 2015). The content of vitamin C in the pepper fruit is higher than in Citrus (Finger et al., 2010). The pepper fruit is a rich source of vitamin A, E, C and P in green chilli (Howard et al., 2000; Marin et al., 2004). They have a high level of vitamins $\mathrm{C}$ and $\mathrm{E}$ as well as the total of antioxidants is completed by phenolic compounds, which occur in peppers in connection with sugars (Shotorbani and Jamei, 2013; Batiha et al., 2020).

Preservation of such plant genetic resources is extremely important for plant breeding as well as for society as a whole (Moreira et al., 2018). In view of the cultural and economic importance of the Capsicum, the development of new and improved cultivars carrying characteristics that meet the needs of farmers and the consumers is primordial. To achieve this goal, plant breeders are dependent on plant genetic resources and need access to the widest genetic diversity available. For these reasons, the preservation of wild species, local varieties and traditional genotypes in collections or germplasm banks is very important (Nass et al., 2012). In addition, the characterization of these materials is essential information for the conservation and use in plant breeding programs (Murillo-Amador et al., 2015; Sarobo, 2019).

Variability study of agro-morphological characteristics of various Capsicum species in conditions of Botanical Garden (Slovakia) due to biodiversity conservation and plant breeding program was aim of our examination.

\section{Materiall and methodology}

\section{Biological material}

We experimentally studied 28 cultivars of peppers from the three Capsicum species (C. annuum, C. baccatum and C. chinense) (Table 1 ). All 28 cultivars of chilli peppers that were 
the subject of the study were grown under green-house conditions in the Botanical Garden, which is located on the area of the Slovak University of Agriculture in Nitra.

Table 1 List of 28 cultivars of Capsicum spp.

\begin{tabular}{|c|c|c|}
\hline No. & Species & Cultivars \\
\hline 1 & Capsicum annuum L. & Black Kobra \\
\hline 2 & Capsicum annuum L. & Chocho \\
\hline 3 & Capsicum annuит L. & Jalapeno \\
\hline 4 & Capsicum annuum L. & Kilian \\
\hline 5 & Capsicum annuum L. & Medusa \\
\hline 6 & Capsicum annuum L. & Pepperoncini Greek \\
\hline 7 & Capsicum annuum L. & Tabasco \\
\hline 8 & Capsicum annuum L. & Trinidad Hot Cherry \\
\hline 9 & Capsicum annuum var. nigrum & Black Prince \\
\hline 10 & Capsicum baccatum L. & Aji Amarilo \\
\hline 11 & Capsicum baccatum $\mathrm{L}$. & Aji fantasy sparkly white \\
\hline 12 & Capsicum baccatum L. & Aji Rojo \\
\hline 13 & Capsicum baccatum L. & Bishops Crown Red \\
\hline 14 & Capsicum baccatum L. & El Oro De Ecuador \\
\hline 15 & Capsicum baccatum L. var. pendulum & Escabeche \\
\hline 16 & Capsicum chinense Jacq. & Aji Charapita \\
\hline 17 & Capsicum chinense Jacq. & Carolina Reaper \\
\hline 18 & Capsicum chinense Jacq. & Citron \\
\hline 19 & Capsicum chinense Jacq. & Fatali Red \\
\hline 20 & Capsicum chinense Jacq. & Fidalgo Roxa \\
\hline 21 & Capsicum chinense Jacq. & Habanero Chocolate \\
\hline 22 & Capsicum chinense Jacq. & Habanero Peach \\
\hline 23 & Capsicum chinense Jacq. & Haba nero Red \\
\hline 24 & Capsicum chinense Jacq. & Habanero Red Savina \\
\hline 25 & Capsicum chinense Jacq. & Jolokia White \\
\hline 26 & Capsicum chinense Jacq. & Peter's Orange \\
\hline 27 & Capsicum chinense Jacq. & Pimenta De Neyde \\
\hline 28 & Capsicum chinense Jacq. & Trinidad Scorpion Peach \\
\hline
\end{tabular}




\section{Morphometrical analysis}

The following quantitative and qualitative properties were evaluated by morphometrical analysis:

a) fruit weight (g); stem weight (g); weight of exocarp (g); ovary weight (g); seed weight (g); number of seeds in fruit (pcs);

b) shape of fruits; fruit shape at peduncle; fruit shape at blossom end; colour of the fruits.

The weights were evaluated by analytical balance (Kern ADB-A01S05, Germany), accurate to $0.01 \mathrm{~g}$.

\section{Statistical analysis}

It was evaluated the variability of the test files in each character using descriptive statistics. For the characteristics of the files, it was used the basic descriptors of variability: average, minimum measured value, maximum measured value, the coefficient of variation (\%). The degree of variability was determined by the coefficient of variation values. The given parameter is independent of the unit of the evaluated character. Theoretically, they can acquire different values (Stehlíková, 1998). Cluster dendrogram were performed in the free software for scientific data analysis PAST 2.17. We used correlation analysis in the program STATISTICA 1.10 to determine the dependence between individual characters.

\section{Results and discussion}

The researched morphological diversity among pepper populations is helpful for breeding programs aimed in selecting superior genotypes. Local or introduced pepper populations is included in broader genetic analyses and considered as a source of new genetic variability used for the development of inbred lines in breeding program.

The evaluation of plant genetic resources has been considered of prime importance, especially in those species having economic importance (Dibuz et al., 1998; Grygorieva et al., 2014, 2017, 2018a, b; Monka et al., 2014; Lima et al., 2017; Ivanišová et al., 2017; Vinogradova et al., 2017; Fatrcová-Šramková et al., 2019; Brindza et al., 2019).

The weight of fruits of chilli pepper cultivars is presented in Table 2. In the evaluated collection was determined the average weight of fruits in the range from $0.318 \mathrm{~g}$ (Aji Charapita) to 25.94 g (Trinidad Hot Cherry). For the complete, we determined the weight of fruits up to $10 \mathrm{~g}$ for 18 cultivars, from 10.1 to $20 \mathrm{~g}$ for 7 cultivars, and the weight of fruits above $20 \mathrm{~g}$ for 3 cultivars. The values of the coefficient of variation were in the interval 9.166-42,020\%, which documented low up to high degree of variability of the character within the collection.

In agreement with our description, similar fruit weight was found by Bianchi et al., (2020) for C. chinense from four Brazilian region and one from Peru (1.04-18.61 g), for cultivated species from West Africa $C$. annuum (5.14 $\pm 0.42-20.97 \pm 2.69)$ and $C$. frutescens $(1.83 \pm 0.25)$ by Olatunji and Afolayan (2019). Jarret and Berke (2008) characterized $C$. chinense from USDA/ARS Capsicum germplasm collection and determined mean fruit weight in a range of 0.18 to $22.7 \mathrm{~g}$. 
Table 2 presents the weights of peduncle, which were determined as the average values in the range from $0.017 \mathrm{~g}$ (Black Prince) to $0.410 \mathrm{~g}$ (Trinidad Hot Cherry). For the complete, we determined the weight of peduncles to $0.10 \mathrm{~g}$ for 16 cultivars, from 0.10 to $0.20 \mathrm{~g}$ for 8 cultivars, and the peduncle weights above $0.20 \mathrm{~g}$ and up for 4 cultivars. The values of coefficients of variation document a medium up to high degree of variability.

Table 2 Statistical characteristics of variability of fruits in the collection of chilli pepper genotypes

\begin{tabular}{|c|c|c|c|c|c|c|c|c|}
\hline \multirow[t]{2}{*}{ Cultivars } & \multicolumn{4}{|c|}{ Fruit weight (g) } & \multicolumn{4}{|c|}{ Peduncle weight (g) } \\
\hline & $\min$ & $\max$ & $\overline{\boldsymbol{x}}$ & V (\%) & $\min$ & $\max$ & $\overline{\boldsymbol{x}}$ & V (\%) \\
\hline Habanero Red & 7.95 & 11.95 & 9,76 & 17.21 & 0.07 & 0.17 & 0.12 & 34.48 \\
\hline Peter'S Orange & 12.65 & 17.81 & 14.66 & 15.40 & 0.27 & 0.41 & 0.33 & 19.24 \\
\hline Tr. Hot Cherry & 21.48 & 29.98 & 25.94 & 12.88 & 0.04 & 0.78 & 0.41 & 68.96 \\
\hline Kilian & 1.43 & 3.51 & 2.32 & 32.38 & 0.01 & 0.06 & 0.02 & 74.06 \\
\hline Tabasco & 1.02 & 2.23 & 1.79 & 27.28 & 0.11 & 0.30 & 0.18 & 42.53 \\
\hline Escabeche & 4.86 & 8.05 & 7.05 & 18.63 & 0.03 & 0.06 & 0.04 & 24.69 \\
\hline Pepper. Greek & 4.71 & 11.36 & 6.53 & 42.02 & 0.03 & 0.13 & 0.09 & 38.69 \\
\hline Fidalgo Roxa & 3.39 & 5.30 & 3.89 & 20.80 & 0.01 & 0.14 & 0.05 & 96.55 \\
\hline Jalapeno & 11.43 & 20.92 & 15.67 & 22.09 & 0.09 & 0.13 & 0.12 & 15.00 \\
\hline Fatali Red & 5.69 & 7.32 & 6.66 & 12.39 & 0.06 & 0.07 & 0.07 & 3.89 \\
\hline Black Kobra & 3.08 & 4.70 & 3.73 & 18.97 & 0.02 & 0.07 & 0.05 & 41.53 \\
\hline Aji Rojo & 16.71 & 27.87 & 23.18 & 19.48 & 0.23 & 0.42 & 0.32 & 22.93 \\
\hline Carolina Reaper & 5.61 & 8.25 & 6.67 & 16.39 & 0.04 & 0.06 & 0.04 & 19.44 \\
\hline Tr. Scorp. Peach & 4.95 & 8.52 & 6.74 & 18.90 & 0.02 & 0.04 & 0.03 & 22.02 \\
\hline Aji Charapita & 0.26 & 0.44 & 0.32 & 22.49 & 0.01 & 0.14 & 0.05 & 100.54 \\
\hline Bishops Cr. Red & 15.90 & 26.87 & 22.60 & 20.11 & 0.07 & 0.16 & 0.10 & 38.74 \\
\hline Black Prince & 0.62 & 1.02 & 0.87 & 17.92 & 0.01 & 0.02 & 0.01 & 18.10 \\
\hline El Oro De Ecuador & 3.93 & 8.08 & 6.08 & 25.66 & 0.07 & 0.17 & 0.12 & 33.54 \\
\hline Chocho & 9.52 & 22.08 & 14.29 & 37.17 & 0.27 & 0.45 & 0.38 & 20.44 \\
\hline Habanero Peach & 11.14 & 16.83 & 14.37 & 17.66 & 0.04 & 0.15 & 0.11 & 37.69 \\
\hline Medusa & 1.72 & 2.28 & 2.10 & 10.67 & 0.07 & 0.08 & 0.07 & 7.20 \\
\hline Jolokia White & 6.69 & 8.66 & 7.75 & 9.77 & 0.06 & 0.08 & 0.07 & 17.20 \\
\hline Habanero Chocolate & 12.31 & 19.28 & 15.39 & 18.85 & 0.03 & 0.08 & 0.06 & 28.69 \\
\hline Pimenta De Neyde & 3.81 & 5.55 & 4.72 & 15.75 & 0.03 & 0.06 & 0.05 & 25.17 \\
\hline Habanero Red S. & 7.49 & 13.35 & 10.50 & 26.19 & 0.03 & 0.10 & 0.06 & 41.13 \\
\hline Citron & 2.08 & 2.63 & 2.30 & 9.16 & 0.04 & 0.07 & 0.05 & 21.30 \\
\hline Aji Amarilo & 4.08 & 6.53 & 5.42 & 17.49 & 0.08 & 0.15 & 0.11 & 24.77 \\
\hline Aji F. Sparkly W. & 10.20 & 14.70 & 12.40 & 14.27 & 0.15 & 0.18 & 0.17 & 7.22 \\
\hline
\end{tabular}

Note: $n$ - the number of measurements; min, max - minimal and maximal measured values; $\bar{x}-$ arithmetic mean; $\mathrm{V}$ - coefficient of variation (\%) 
The exocarp weight of the evaluated chilli pepper cultivars is presented in Table 3. It was determined the average exocarp weight in the range from $0.244 \mathrm{~g}$ (Aji Charapita) to $24.601 \mathrm{~g}$ (Trinidad Hot Cherry). For the complete, we determined the weight of exocarp up to $10 \mathrm{~g}$ in 20 cultivars, from 10.1 to $20 \mathrm{~g}$ in 5 cultivars and the weight of the exocarp from above $20 \mathrm{~g}$ upwards in 3 cultivars. The values of coefficients of variation document a medium up to high degree of variability.

Table 3 Statistical characteristics of variability of exocarp weight and number of seeds per fruit in the collection of chilli pepper genotypes

\begin{tabular}{|c|c|c|c|c|c|c|c|c|}
\hline \multirow[t]{2}{*}{ Cultivar } & \multicolumn{4}{|c|}{ Number Of Seeds Per Fruit (Pcs) } & \multicolumn{4}{|c|}{ Number Of Seeds Per Fruit (Pcs) } \\
\hline & $\min$ & $\max$ & $\bar{x}$ & V (\%) & $\min$ & $\max$ & $\overline{\boldsymbol{x}}$ & V (\%) \\
\hline Habanero Red & 7.85 & 11.69 & 9.62 & 16.86 & 35 & 57 & 43.80 & 20.06 \\
\hline Peter's Orange & 12.33 & 17.41 & 14.31 & 15.65 & 55 & 86 & 67.20 & 18.98 \\
\hline Tr. Hot Cherry & 20.50 & 28.33 & 24.60 & 12.67 & 158 & 243 & 185.80 & 18.34 \\
\hline Kilian & 0.99 & 2.71 & 1.76 & 34.60 & 18 & 49 & 35.40 & 39.07 \\
\hline Tabasco & 0.89 & 2.00 & 1.58 & 28.09 & 20 & 72 & 46.60 & 47.44 \\
\hline Escabeche & 3.62 & 7.19 & 5.55 & 23.84 & 2 & 52 & 43.60 & 27.36 \\
\hline Pepper. Greek & 3.99 & 10.62 & 5.76 & 47.73 & 116 & 170 & 139.60 & 16.75 \\
\hline Fidalgo Roxa & 3.16 & 5.10 & 3.70 & 21.72 & 10 & 40 & 23.00 & 52.17 \\
\hline Jalapeno & 11.20 & 20.57 & 15.38 & 22.22 & 37 & 106 & 74.80 & 33.14 \\
\hline Fatali Red & 5.46 & 7.05 & 6.44 & 12.77 & 12 & 41 & 26.00 & 47.73 \\
\hline Black Kobra & 2.70 & 4.24 & 3.33 & 20.22 & 46 & 72 & 60.40 & 18.68 \\
\hline Aji Rojo & 15.49 & 25.94 & 21.70 & 19.31 & 52 & 139 & 100.20 & 33.81 \\
\hline Carolina Reaper & 4.96 & 7.53 & 6.02 & 17.56 & 14 & 44 & 28.00 & 44.67 \\
\hline Tr. Scorp. Peach & 4.81 & 8.32 & 6.58 & 19.01 & 4 & 23 & 14.20 & 62.07 \\
\hline Aji Charapita & 0.22 & 0.27 & 0.24 & 8.49 & 15 & 17 & 16.00 & 6.25 \\
\hline Bishops Cr. Red & 13.49 & 25.45 & 20.69 & 25.31 & 34 & 136 & 81.40 & 44.72 \\
\hline Black Prince & 0.52 & 0.88 & 0.76 & 18.86 & 15 & 41 & 31.80 & 33.23 \\
\hline El Oro De Ecuador & 3.85 & 7.80 & 5.94 & 25.30 & 6 & 37 & 27.20 & 46.16 \\
\hline Chocho & 2.00 & 15.54 & 9.14 & 53.44 & 75 & 166 & 115.40 & 35.91 \\
\hline Habanero Peach & 11.00 & 16.61 & 14.22 & 17.61 & 43 & 76 & 52.60 & 26.19 \\
\hline Medusa & 1.14 & 1.62 & 1.43 & 12.77 & 38 & 78 & 60.80 & 24.76 \\
\hline Jolokia White & 6.60 & 8.56 & 7.64 & 9.88 & 16 & 56 & 28.20 & 57.85 \\
\hline Habanero Chocolate & 12.01 & 18.88 & 15.05 & 18.95 & 38 & 76 & 59.20 & 23.47 \\
\hline Pimenta De Neyde & 2.89 & 4.73 & 3.87 & 18.94 & 19 & 64 & 39.20 & 42.12 \\
\hline Habanero Red S. & 6.90 & 12.24 & 9.66 & 26.39 & 25 & 63 & 37.20 & 43.36 \\
\hline Citron & 1.50 & 2.00 & 1.74 & 13.09 & 36 & 47 & 39.60 & 10.94 \\
\hline Aji Amarilo & 4.00 & 6.37 & 5.31 & 17.30 & 30 & 131 & 91.20 & 40.64 \\
\hline Aji F. Sparkly White & 10.05 & 14.48 & 12.17 & 14.20 & 25 & 102 & 70.60 & 41.01 \\
\hline
\end{tabular}

Note: $n$ - the number of measurements; min, max - minimal and maximal measured values; $\bar{x}$ - arithmetic mean; $\mathrm{V}$ - coefficient of variation (\%) 
Table 3 presents the number of seeds per fruit. We determined the average number of seeds in the range from 14.2 pieces (Trinidad Scorpion Peach) to 185.8 pieces (Trinidad Hot Cherry). For the complete, we determined the number of seeds up to 50 pieces for 13 cultivars, from 51 to 100 pieces for 9 cultivars and the number of seeds over 100 pieces for 4 cultivars. The values of the coefficients of variation document a medium up to high degree of variability. Comparison our values with other authors showed similar results, e.g. by Zhigila et al. (2013) seeds per fruit were determined in five varieties C. annuum L. in Nigeria (39-44 and 97-122 pcs), Carvalho et al. (2017) studied Brazilian C. frutescens $L$. fruit features and determined seeds below 20 pcs per fruit.

The ovary weight of the evaluated chilli pepper cultivars is presented in Table 4 . We determined the average ovary weight in the range from $0.174 \mathrm{~g}$ (Aji Charapita) to $4.920 \mathrm{~g}$ (Trinidad Hot Cherry). For the complete, we determined the ovary weight up to $1 \mathrm{~g}$ for 16 cultivars, from 1.1 to $2 \mathrm{~g}$ for 5 cultivars and the ovary weight over $2 \mathrm{~g}$ for 7 cultivars. The values of coefficients of variation document a medium up to high degree of variability.

Table 4 presents the seed weight. We determined the average seed weight in the range from $0.046 \mathrm{~g}$ (Aji Charapita) to $2.146 \mathrm{~g}$ (Chocho). For the complete, we determined the seed weight up to $1 \mathrm{~g}$ for 24 cultivars, from 1 to $2 \mathrm{~g}$ for 3 cultivars and the seed weight above $2 \mathrm{~g}$ for 1 cultivar. The values of coefficients of variation document a medium up to high degree of variability.

Dias et al. (2013) studied weight of 1000 seeds (g) for C. chinense (6.57 g), C. annuum (5.18 g), C. baccatum (5.91 g) and C. frutescens (4.29 g) in Brazil. Nsabiyera et al. (2012) characterized weight of 300 seeds $C$. annuum of 10 local $(1.5 \mathrm{~g})$ and 27 exotic introduced genotypes (1. g) in Uganda regions. Results from West Africa by Olatunji and Afolayan (2019) showed for two cultivated species $C$. annuum and $C$. frutescens number of seeds per fruit values $18.70 \pm 2.54-118.50 \pm 14.91$ and $24.10 \pm 2.20$, respectively.

For a more complex assessment of the issue was determined the linear dependence between the weight of fruit and weight of exocarp and other traits. In both evaluated variants was determined a positive statistically high dependence between fruit weight and exocarp weight, with one exception. A similar dependence was also found between exocarp weight and ovary weight, with few exceptions. The correlation linear dependence between some features of the evaluated chilli pepper cultivars is presented in Table 5. 
Table 4 Statistical characteristics of variability of ovary weight and seed weight in the collection of chilli pepper genotypes

\begin{tabular}{|c|c|c|c|c|c|c|c|c|}
\hline \multirow[t]{2}{*}{ Cultivar } & \multicolumn{4}{|c|}{ Ovary weight (g) } & \multicolumn{4}{|c|}{ Seed weight (g) } \\
\hline & $\min$ & $\max$ & $\bar{x}$ & V (\%) & $\min$ & $\max$ & $\overline{\boldsymbol{x}}$ & V (\%) \\
\hline Habanero Red & 0.80 & 1.23 & 0.99 & 17.65 & 0.27 & 0.42 & 0.36 & 16.78 \\
\hline Peter's Orange & 1.12 & 1.68 & 1.32 & 17.44 & 0.55 & 0.85 & 0.67 & 18.75 \\
\hline Tr. Hot Cherry & 4.15 & 5.77 & 4.92 & 14.15 & 1.60 & 1.91 & 1.75 & 8.61 \\
\hline Kilian & 0.31 & 0.58 & 0.45 & 25.13 & 0.15 & 0.38 & 0.25 & 39.30 \\
\hline Tabasco & 0.28 & 0.84 & 0.62 & 37.34 & 0.13 & 0.57 & 0.33 & 52.16 \\
\hline Escabeche & 0.50 & 0.81 & 0.66 & 18.65 & 0.19 & 0.40 & 0.33 & 25.51 \\
\hline Pepper. Greek & 1.61 & 2.01 & 1.84 & 10.05 & 0.94 & 1.09 & 1.02 & 6.16 \\
\hline Fidalgo Roxa & 0.35 & 0.71 & 0.49 & 29.98 & 0.06 & 0.28 & 0.13 & 62.93 \\
\hline Jalapeno & 1.42 & 3.71 & 2.21 & 39.64 & 0.45 & 1.45 & 0.82 & 46.90 \\
\hline Fatali Red & 0.57 & 3.04 & 1.69 & 69.34 & 0.11 & 0.36 & 0.22 & 42.83 \\
\hline Black Kobra & 0.65 & 1.14 & 0.90 & 20.08 & 0.23 & 0.61 & 0.42 & 34.10 \\
\hline Aji Rojo & 1.48 & 3.83 & 2.58 & 33.62 & 0.58 & 1.55 & 1.04 & 34.30 \\
\hline Carolina Reaper & 0.28 & 0.94 & 0.55 & 45.01 & 0.13 & 0.54 & 0.30 & 49.91 \\
\hline Tr. Scorp. Peach & 0.26 & 1.05 & 0.57 & 52.28 & 0.01 & 0.58 & 0.19 & 119.65 \\
\hline Aji Charapita & 0.05 & 0.60 & 0.17 & 137.30 & 0.04 & 0.05 & 0.04 & 11.90 \\
\hline Bishops Cr. Red & 1.56 & 3.31 & 2.31 & 28.11 & 0.42 & 1.41 & 0.85 & 41.72 \\
\hline Black Prince & 0.12 & 0.30 & 0.22 & 27.71 & 0.07 & 0.17 & 0.14 & 25.46 \\
\hline El Oro De Ecuador & 0.21 & 0.72 & 0.54 & 36.65 & 0.06 & 0.38 & 0.27 & 45.11 \\
\hline Chocho & 1.82 & 3.62 & 2.74 & 31.58 & 0.85 & 5.74 & 2.14 & 95.90 \\
\hline Habanero Peach & 1.38 & 2.71 & 2.25 & 22.84 & 0.43 & 0.70 & 0.51 & 22.12 \\
\hline Medusa & 0.23 & 0.41 & 0.35 & 20.42 & 0.17 & 0.29 & 0.24 & 18.40 \\
\hline Jolokia White & 0.72 & 3.58 & 1.99 & 70.45 & 0.12 & 0.47 & 0.23 & 60.31 \\
\hline Habanero Chocolate & 1.71 & 3.14 & 2.15 & 27.23 & 0.48 & 0.93 & 0.75 & 22.98 \\
\hline Pimenta De Neyde & 0.44 & 0.76 & 0.61 & 18.47 & 0.16 & 0.32 & 0.27 & 23.23 \\
\hline Habanero Red S. & 0.53 & 1.20 & 0.77 & 39.48 & 0.22 & 0.54 & 0.32 & 41.70 \\
\hline Citron & 0.54 & 0.62 & 0.56 & 6.18 & 0.33 & 0.42 & 0.36 & 9.86 \\
\hline Aji Amarilo & 0.38 & 1.24 & 0.85 & 36.76 & 0.24 & 0.95 & 0.64 & 40.06 \\
\hline Aji F. Sparkly White & 1.21 & 2.16 & 1.54 & 24.11 & 0.21 & 0.81 & 0.53 & 40.57 \\
\hline
\end{tabular}

Note: $n$ - the number of measurements; min, max - minimal and maximal measured values; $\bar{x}$ - arithmetic mean; $\mathrm{V}$ - coefficient of variation (\%). 


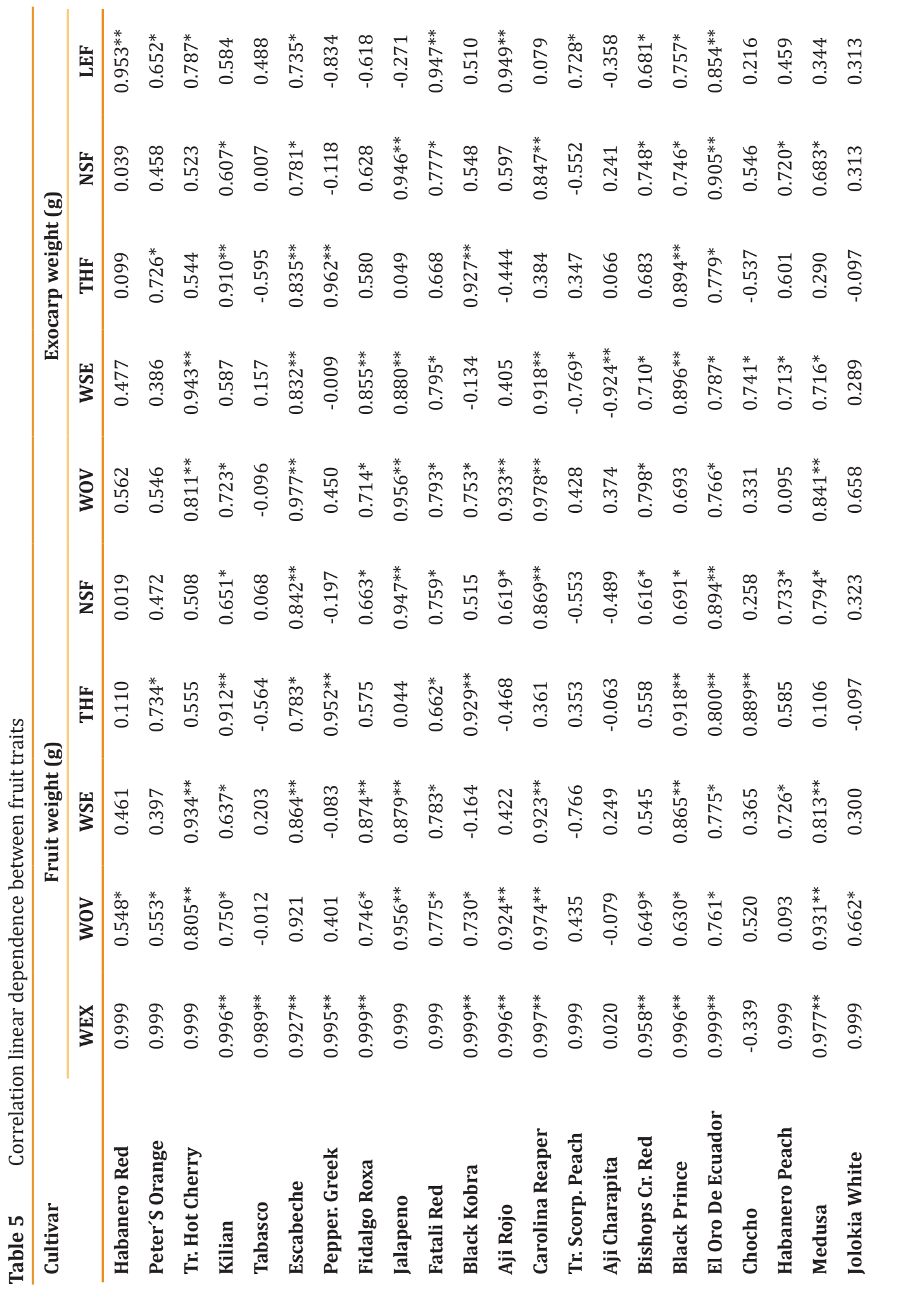




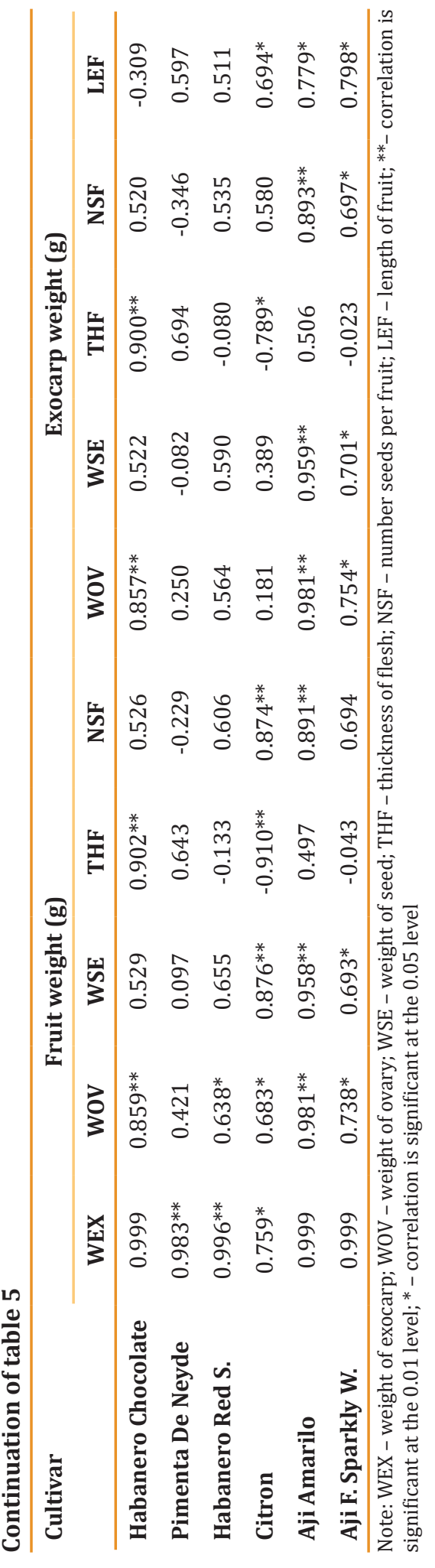




\section{Shape and colour of fruits}

In Figure 1 we present the shape and colour of the fruits of the evaluated chilli pepper cultivars. The comparison shows a significant variability of both traits and extreme differences between cultivars, which are also important distinguishing features of individual varieties. The shape of fruits is characterized as campanulate, blocky, ovoid, round, almost round, linear, triangular, rectangular, elongate etc. Fruit shapes at peduncle attachment were described as lobate, cordate or truncate, fruit shapes at blossom end were described as sunken or pointed (Figure 1). The colour of the fruit can also be misleading, as each variety has a different length of vegetative period and sometimes varieties with a longer vegetative period do not have enough time to reach full technological maturity. Mature fruit colours included red, orange, yellow, brown (chocolate), and cream. In many cases the colouring of fruits with the presence of natural dyes in the flesh also determines the fruit antioxidant activity (Rodríguez-Maturino et al., 2011; Medina-Juárez et al., 2012).

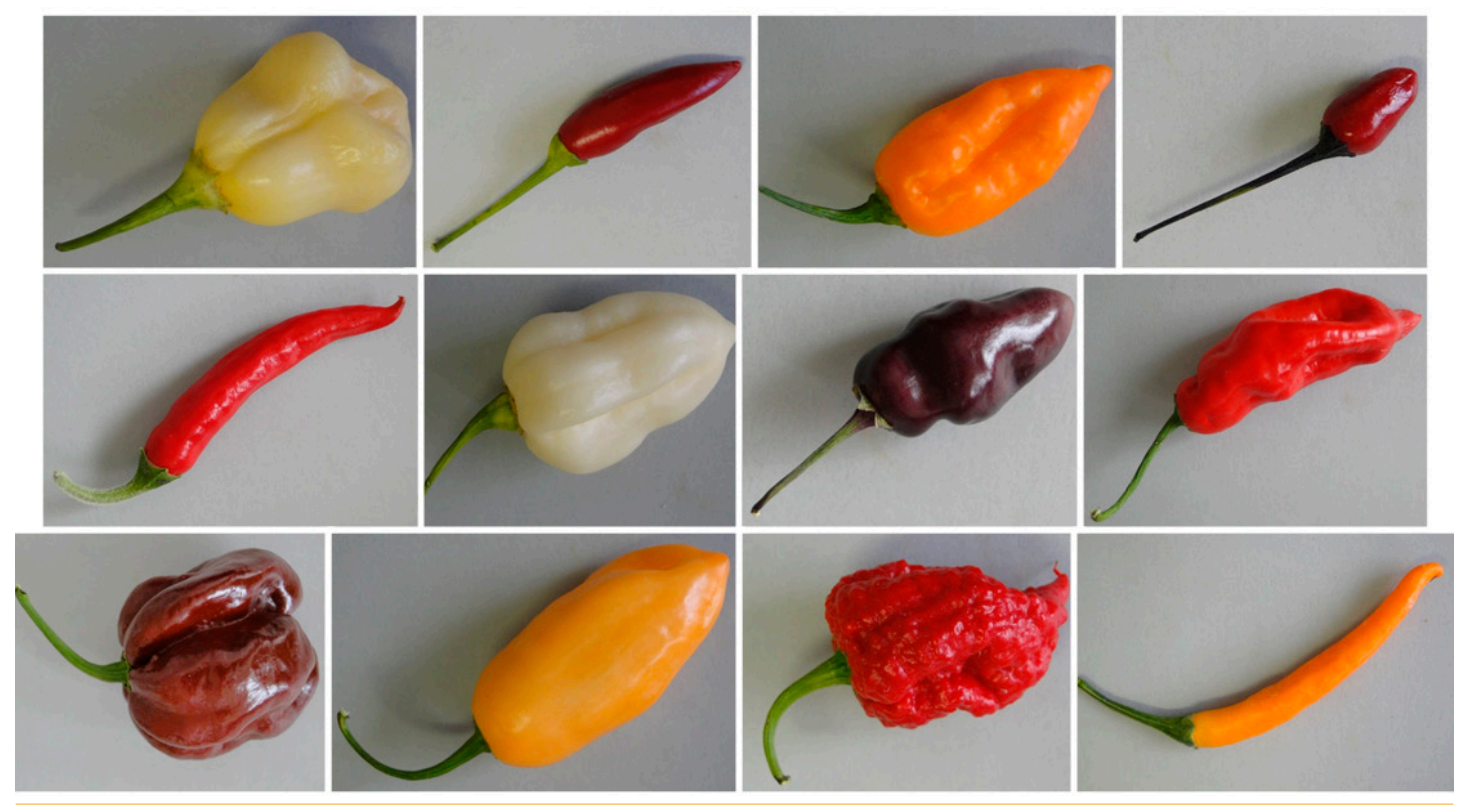

Figure 1 Shape and colour of fruits of evaluated cultivars of chilli pepper (Photo: V. Horčinová Sedláčková, A. Oravec, 2018)

Figure 2 presents a longitudinal section of the fruits of chilli pepper cultivars, in which the number of seeds per fruit was evaluated. The comparison shows significant variability in the given trait and large differences between cultivars. The number of seeds per fruit has a significant effect on the multiplications of individual cultivars.

Figure 3 presents a cross-section of the fruits of the evaluated cultivars of chilli pepper, in which we evaluated the width of the fruit and the thickness of the flesh. The comparison shows a relatively high variability in both features. The fruit width and the flesh thickness determine the total weight of the fruit and thus the amount of dry matter in the fruit. 


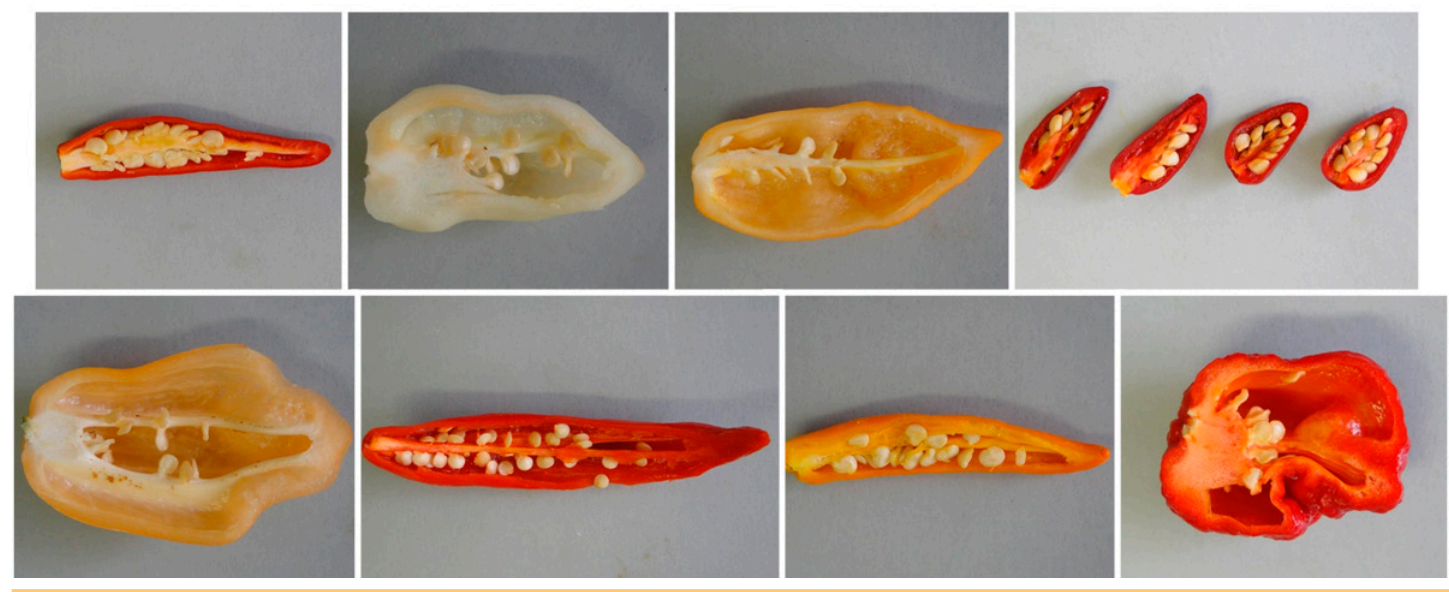

Figure 2 Comparison of evaluated cultivars of chilli pepper in longitudinal section of fruits (Photo: V. Horčinová Sedláčková, A. Oravec, 2018)

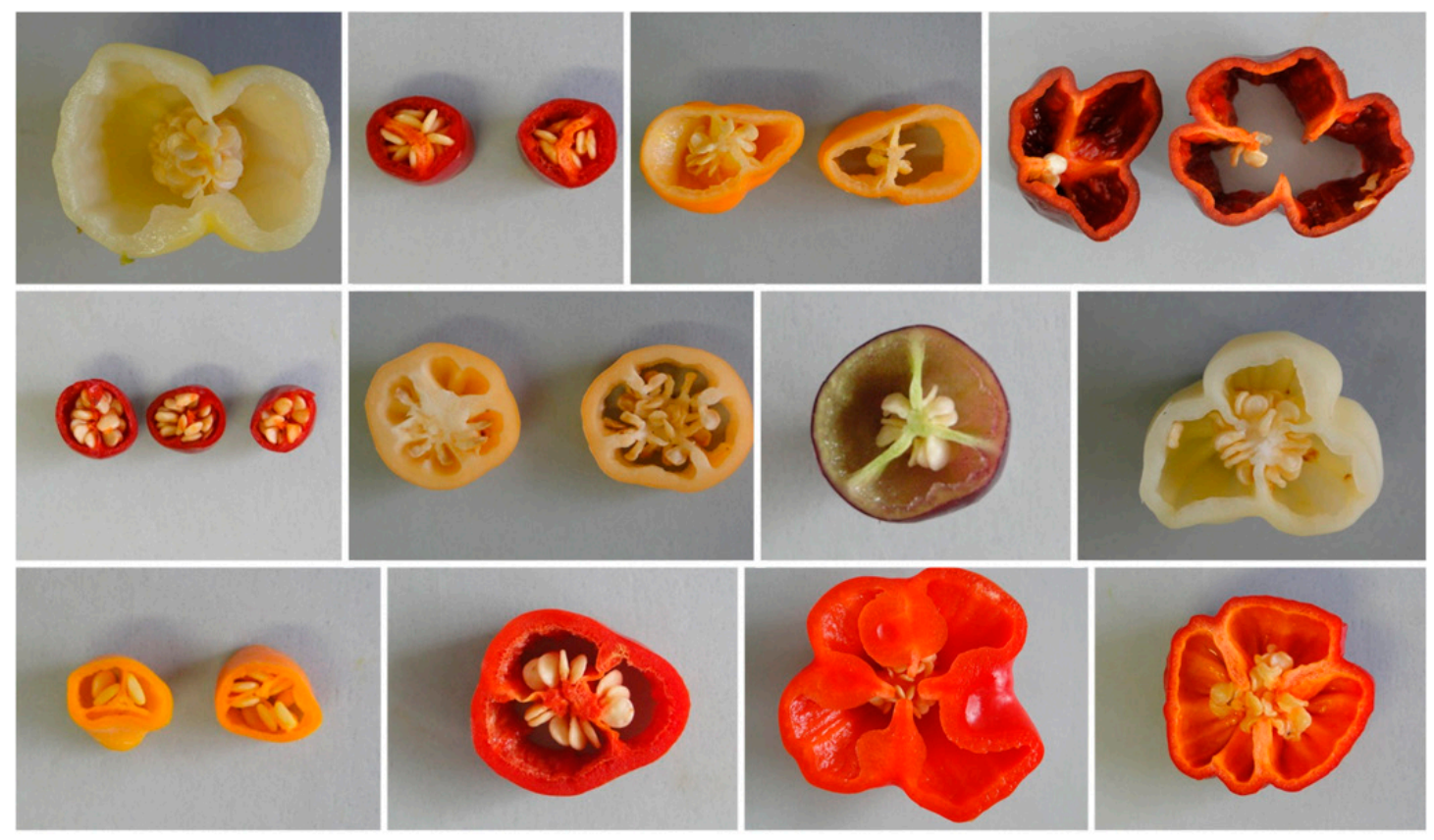

Figure 3 Comparison of the evaluated cultivars of chilli pepper in the cross section of the fruit (Photo: V. Horčinová Sedláčková, A. Oravec, 2018)

Examine of variability for fruit-related traits to select the suitable genetic material has been also shown in other Capsicum spp. studies (Carvalho et al., 2017; Bicikliski et al., 2018; Olatunji and Afolayan, 2019; Bianchi et al., 2020). Genetic diversity of characters of chilli peppers based on phenotypic and molecular descriptors have been studied by several authors (Bozokalfa et al., 2009; Dias et al., 2013; Moreira et al., 2018). However, most of them focused in morphological descriptors of fruit and fewer ones have examined a broad range 
of morpho-agronomic descriptors including both qualitative and quantitative traits (Orobiyi et al., 2018; Andrade et al., 2020; Bianchi et al., 2020).

The documentation obtained from the evaluation of chilli pepper fruits confirms the significant variability of qualitative as well as quantitative features. Results from the correlation analysis (Table 5) and the cluster analysis (Figure 4) confirm the statistically significant differences between the cultivars.

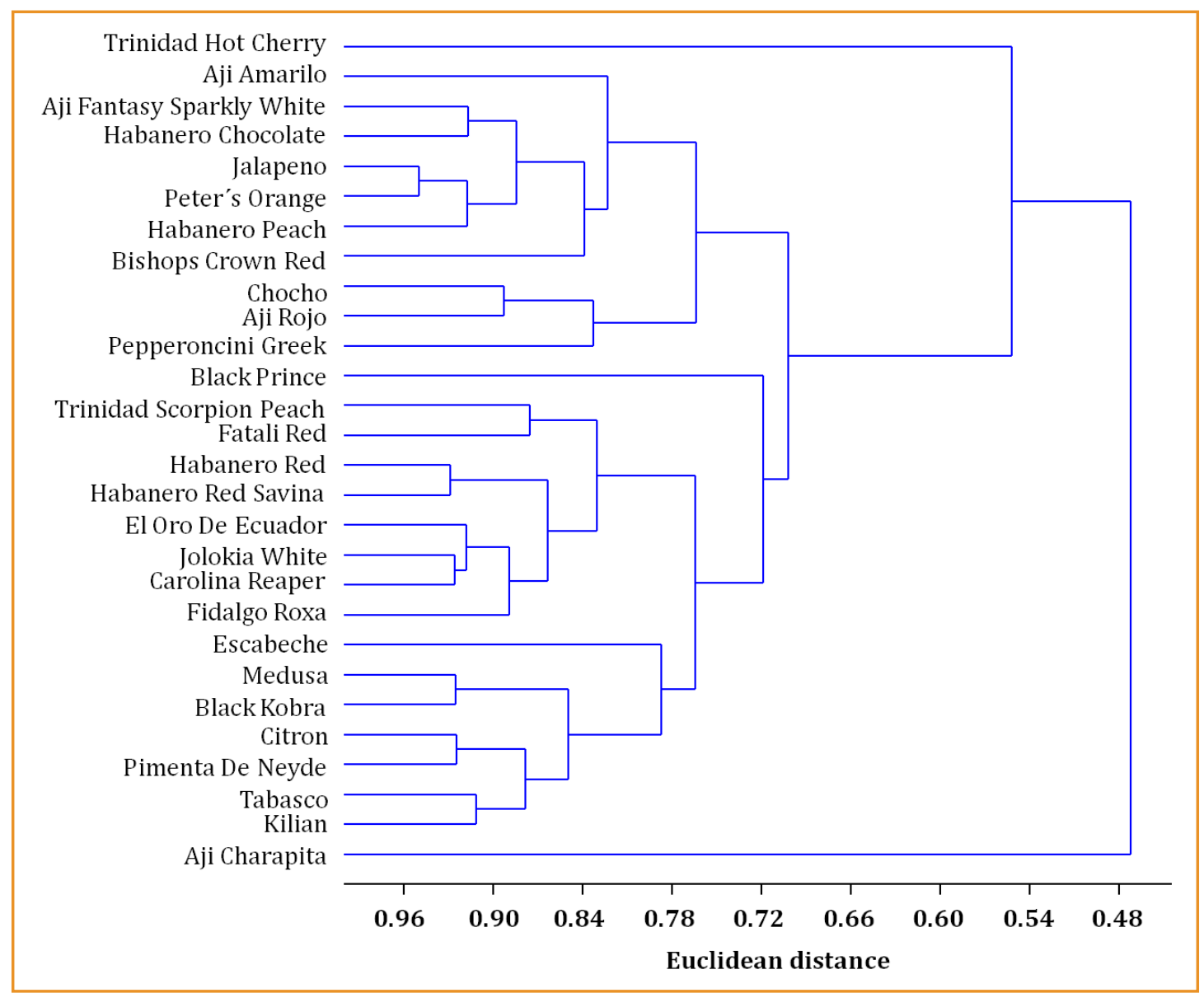

Figure 4 Dendrogram of 28 cultivars of chilli peppers based on morphometric characteristics of fruits

The information gathered from cluster analysis are useful to identify genetic variability among plants. Clustering of genotypes signifies close genetic affinity between/among species and can be used in resolving taxonomic complexities (Olatunji and Afolayan, 2019).

The result from the cluster analysis indicated that there was considerable variability among the cultivars of three Capsicum species which allowed them to be separated into distinct groups (Figure 4). The cluster analysis from 6 quantitative morphological traits examined that Capsicum spp. cultivars were divided into six clusters. Cluster II, IV and cluster V contained the 
largest number of genotypes. Cluster I (Trinidad Hot Cherry with the highest mean values) and cluster III (Black Prince) and Cluster VI (Aji Charapita with the lowest mean values) contained only cultivar, which differ from other genotypes of collection by all parameters.

Many other authors have used cluster analysis to study morphological characters of chilli peppers (Nsabiyera et al., 2013; Orobiyi et al., 2018; Olatunji and Afolayan, 2019; Andrade et al., 2020). Based on the distance between species of different clusters, contrasting parents may be identified and used in hybridization program for generating wider variability for selection and crop improvement (Sarobo, 2019).

\section{Conclusions}

Our results clearly confirmed statistically significant differences between the evaluated pepper cultivars in all examined traits. The results contribute to the expansion of theoretical and practical knowledge about some basic morphometric and production characteristics of chilli pepper fruits in the conditions of Slovakia. Many tested cultivars of chilli peppers are promising for their cultivation, distribution as ornamental plants and processing into food products, especially for small, young and family farms, which can significantly contribute to their socio-economic development and environmental improvement.

\section{Acknowledgement}

The publication was created in cooperation with the international network AgroBioNet in the implementation of the international project in the program "Agrobiodiversity for improve nutrition, health and quality of life" and in the project AgroBioTech (ITEBIO-ITMS 26220220115).

\section{References}

ALIU, S., RUSINOVCI, I., FETAHU, S., KAÇIU, S., ZEKA, D. 2017. Assessment of morphological variability and chemical composition of some local pepper (Capsicum annuum L.) populations on the area of Kosovo. In Acta agriculturae Slovenica, vol. 109(2), p. 205-213. https://doi.org/10.14720/ aas.2017.109.2.05

ANDRADE, N.J.P., MONTEROS-ALTAMIRANO, A., BASTIDAS, C.G.T., SØRENSEN, M. 2020. Morphological, sensorial and chemical characterization of chilli peppers (Capsicum spp.) from the CATIE genebank. In Agronomy, vol. 10(1732), p. 1-18. https://doi.org/10.3390/agronomy10111732

BALLINA-GÓMEZ, H., LATOURNERIE-MORENO, L., RUIZ-SÁNCHEZ, E., PÉREZ-GUTIÉRREZ, A., ROSADO-LUGO, G. 2013. Morphological chracterization of Capsicum annuum L. accessions from southern Mexico and their response to the Bemisia tabaci-Begomovirus complex. In Chilean Journal of Agricultural Research, vol. 73(4), p. 329-338. https://doi.org/10.4067/ S0718-58392013000400001

BARBOSA, R,I., MOURAO JÚNIOR., M., DE F. LUZ, FJ. 2010. Morphometric patterns and preferential uses of Capsicum peppers in the State of Roraima, Brazilian Amazonia. In Horticultura Brasileira, vol. 28(4), p. 477-482.

BARBOZA, G.E., CARRIZO GARCIA, C., LEIVA GONZÁLEZ, S., SCALDAFERRO, M., REYES, X. 2019. Four new species of Capsicum (Solanaceae) from the tropical Andes and an update on the phylogeny of the genus. In PLoSONE, vol. 14(1), p. e0209792. https://doi.org/10.1371/journal.pone.0209792

BASU, S.K., DE, A.K. 2003. Capsicum: historical and botanical perspectives. In DE, A.K., editor. Capsicum. The genus Capsicum. London and New York : Taylor \& Francis, p. 1-15. 
BATIHA, G. E.-S., ALGAHTANI, A., OJO, O.A., SHAHEEN, H.M., WASEF, L., ELZEINY, M., ISMALI, M., SHALABY, M., MURATA, T., ZARAGOZA-BASTIDA, A., RIVERO-PEREZ, N., BESHBISHY, A.M., KASOZI, K.I., JEANDET, P., HETTA, H.F. 2020. Biological properties, bioactive constituents, and pharmacokinetics of some Capsicum spp. and capsaicinoids. In Int J Mol Sci, vol. 21(15), p. 5179. https://doi. org/10.3390/ijms21155179

BIANCHI, P.A., DA SILVA, L.R.A., DA SILVA ALENCAR, A.A., DINIZ SANTOS, P.H.A., PIMENTA, S., SUDRÉ, C.P., ERPEN-DALLA CORTE, L., GONÇALVES, L.S.A., RODRIGUES, R. 2020. Biomorphological characterization of Brazilian Capsicum chinense Jacq. germplasm In Agronomy, vol. 10 (447), p. 1-17. https://doi.org/10.3390/agronomy10030447

BICIKLISKI, O., TRAJKOVKA, F., MIHAJLOV, L. 2018. Morphological characteristics of some pepper genotypes (Capsicum annuum L.) grown in conventional and organic agricultural systems: Comparative analysis. In Annual Research and Review in Biology, vol. 28(3), p. 1-11. https://doi. org/10.9734/ARRB/2018/43308

BOZOKALFA, K., ESIYOK, D., TURHAN, K. 2009. Patterns of phenotypic variation in a germplasm collection of pepper (Capsicum annuum L) from Turkey. In Spanish Journal of Agricultural Research, vol. 1, p. 83-95. https://doi.org/10.5424/sjar/2009071-401

BRINDZA, J., GRYGORIEVA, O., KLYMENKO, S., VERGUN, O., MAREČEK, J., IVANIŠOVÁ, E. 2019. Variation of fruits morphometric parameters and bioactive compounds of Asimina triloba (L.) Dunal germplasm collection. In Potravinarstvo Slovak Journal of Food Sciences, vol. 13(1), p. 1-7. https:// doi.org/10.5219/1019

CARVALHO, S.I.C., BIANCHETTI, L.B., RAGASSI, C.F., RIBEIRO, C.S.C., REIFSCHNEIDER, F.J.B., BUSO, G.S.C., FALEIRO, F.G. 2017. Genetic variability of a Brazilian Capsicum frutescens germplasm collection using morphological characteristics and SSR markers. In Genetics and Molecular Research, vol. 16 (3), p. 1-18. http://dx.doi.org/10.4238/gmr16039689

CSILLERY, G. 2006. Pepper taxonomy and the botanical description of the species. In Acta Agronomica Hungarica, vol. 54, p. 151-166. https://doi.org/10.1556/AAgr.54.2006.2.5

DEWITT, D., BOSLAND, P.W. 2009. Complete Chile Pepper Book: A Gardener's Guide to Choosing, Growing, Preserving, and Cooking, Portland, London : Timber Press. $336 \mathrm{p}$.

DIAS, G.B., GOMES, V.M., MORAES, T.M.S., ZOTTICH, U.P., RABELO, G.R., CARVALHO, A.O., MOULIN, M., GONÇALVES, L.S.A., RODRIGUES, R., CUNHA, M.D. 2013. Characterization of Capsicum species using anatomical and molecular data. In Genetics and Molecular Research, vol. 12(4), p. 6488-6501. http://dx.doi.org/10.4238/2013.February.28.29

DIBUZ, E., SOLTÉSZ, M., NYÉKI, J. 1998. Morphological characteristics of seeds grown in the fruits of pear cultivars. In Acta Hortic., vol. 475, p. 435-438. https://doi.org/10.17660/ActaHortic.1998.475.54

FATRCOVÁ-ŠRAMKOVÁ, K., BRINDZA, J., IVANIŠOVÁ, E., JURÍKOVÁ, T., SCHWARZOVÁ, M., HORČINOVÁ SEDLÁČKOVÁ, V., GRYGORIEVA, O. 2019. Morphological and antiradical characteristics of Rugosa rose (Rosa rugosa Thunb.) fruits canned in different kind of honeys and in beverages prepared from honey. In Potravinarstvo Slovak Journal of Food Sciences, vol. 13(1), p. 497-506. https://doi. org/10.5219/1065

GRYGORIEVA, O., ABRAHAMOVÁ, V., KARNATOVSKÁ, M., BLEHA, R., BRINDZA, J. 2014. Morphological characteristic of fruit, drupes and seeds genotypes of Ziziphus jujuba Mill. In Potravinarstvo Slovak Journal of Food Sciences, vol. 8(1), p. 306-314. https://doi.org/10.5219/414

GRYGORIEVA, O., KLYMENKO, S., BRINDZA, J., SCHUBERTOVÁ, Z., NIKOLAIEVA, N., ŠIMKOVÁ, J. 2017. Morphometric characteristics of sweet chestnut (Castanea sativa Mill.) fruits. In Potravinarstvo Slovak Journal of Food Sciences, vol. 11(1), p. 288-295. https://doi.org/10.5219/684

GRYGORIEVA, O., KLYMENKO, S., ILINSKA, A., BRINDZA, J. 2018a. Variation of fruits morphometric parameters of Elaeagnus multiflora Thunb. germplasm collection. In Potravinarstvo Slovak Journal of Food Sciences, vol. 12(1), p. 527-532. 10.5219/922 
GRYGORIEVA, O., KLYMENKO, S., VINOGRADOVA, YU., VERGUN, O., BRINDZA, J. 2018b. Variation in morphometric traits of fruits of Mespilus germanica L. In Potravinarstvo Slovak Journal of Food Sciences, vol. 12(1), p. 782-788. https://doi.org/10.5219/999

HOWARD, L.R., TALCOTT, S.T., BRENES, C.H., VILLALON, B. 2000. Changes in phytochemical and antioxidant activity of selected pepper cultivars (Capsicum species) as influenced by maturity. In Journal of Agricultural and Food Chemistry, vol. 48, p. 1713-1720. https://doi.org/10.1021/ jf990916t

IVANIŠOVÁ, E., GRYGORIEVA, O., ABRAHAMOVÁ, V., SCHUBERTOVÁ, Z., TERENTJEVA, M., BRINDZA, J. 2017. Characterization of morphological parameters and biological activity of jujube fruit (Ziziphus jujuba Mill.). In Journal of Berry research, vol. 7(4), p. 249-260. http://dx.doi.org/10.3233/ ذBR-170162

JARRET, R. L., LEVY, I. J., POTTER, T. L., CERMAK, S. C. 2013. Seed oil and fatty acid composition in Capsicum spp. In Journal of Food Composition and Analysis, vol. 30(2), p. 102-108. https://doi. org/10.1016/j.jfca.2013.02.005

LAWRENCE JARRET, R., BERKE, T. 2008. Variation for fruit morphological characteristics in a Capsicum chinense Jacq. germplasm collection. In Horticulture Science, vol. 43(6), p. 1694-1697.

LIMA, L.F., LIMA, R.G.V., N., FERREIRA, A.C., ALMEIDA, E.B., CARMEN, S.Z. 2017. Morphological characterization of fruit, seeds and seedlings of white-seal (Chrysophyllum rufum Mart. - Sapotaceae). In Biota Neotrop, vol.17(4), p. e20170355. https://doi. org/10.1590/1676-0611-bn-2017-0355

MARIN, A., FERRERES, F., TOMAS-BARBERAN, F.A., GIL, M.I. 2004. Characterization and quantitation of antioxidant constituents of sweet pepper (Capsicum annuum L). In Journal of Agricultural and Food Chemistry, vol. 52, p. 3861-3869. https://doi.org/10.1021/if0497915

MEDINA-JUÁREZ, L. A., MOLINA-QUIJADA, D.M.A., DEL TORO-SÁNCHEZ, C., GONZÁLEZ-AGUILAR, G., GÁMEZ-MEZA, N. 2012. Antioxidant activity of peppers (Capsicum annuum L.) extracts and characterization of their phenolic constituents. In Interciencia, vol. 37(8), p. 588-593. https:// www.interciencia.net/wp-content/uploads/2018/01/588-c-1\%C2\%BA-GAMEZ-MESA-6.pdf

MONKA, A., GRYGORIEVA, O., CHLEBO, P., BRINDZA, J. 2014. Morphological and antioxidant characteristics of quince (Cydonia oblonga Mill.) and Chinese quince fruit (Pseudocydonia sinensis Schneid.). In Potravinarstvo Slovak Journal of Food Sciences, vol. 8, p. 333-340. https://doi. org/10.5219/415

MOREIRA, A.F.P., RUAS, P.M., RUAS, C.F., BABA, V.Y., GIORDANI, W., ARRUDA, I.M., RODRIGUES, R., GONÇALVES, L.S.A. 2018. Genetic diversity, population structure and genetic parameters of fruit traits in Capsicum Chinese. In Sci. Hortic., vol. 236, p. 1-9. https://doi.org/10.1016/j. scienta.2018.03.012

MURILLO-AMADOR, B., RUEDA-PUENTE, O., TROYO-DIÉGUEZ. E., CÓRDOBA-MATSON, M.V., HÉRNANDEZ-MONTIEL, L.G., NIETO-GARIBAY, A. 2015. Baseline study of morphometric traits of wild Capsicum annuum growing near two biosphere reserves in the Peninsula of Baja California for future conservation management. In BMC Plant Biology, vol. 15, p. 1-18. https://doi. org/10.1186/s12870-015-0505-6

NADI, M.S., FIKRI, F., PURNAMA, M.T.E. 2020. Determination of capsaicin levels in Capsicum annuum Linn ethanolic extract using thin layer chromatography analysis. In Sys Rev Pharm, vol. 11(6), p. 661-664. https://doi.org/10.31838/srp.2020.6.98

NASS, L.L., SIGRIST, M.S., RIBEIRO, C.S.C., REIFSCHNEIDER, F.J.B. 2012. Genetic resources: The basis for sustainable and competitive plant breeding. In Crop Breed. Appl. Biotechnol., vol. 12, p. 75-86. https://doi.org/10.1590/S1984-70332012000500009

NSABIYERA, V., LOGOSE, M., OCHWO-SSEMAKULA, M., SSERUWAGI, P., GIBSON, P., OJIEWO, C. 2013. Morphological characterization of local and exotic hot pepper (Capsicum annuum L.) collections in Uganda. In Bioremediation, Biodiversity and Bioavailability, vol. 7(1), p. 22-32. 
NWACHUKWU C.U., MBAGWU F.N., ONYEJI A. N. 2007. Morphological and leaf epidermal features of Capsicum annum and Capsicum frutescens Solanaceae. In Nature and Science, vol. 5(3), p. 54-60. https://doi.org/47.15835/nbha47111204

OLATUNJI, T.L., AFOLAYAN, A.J. 2019. Contributions to the classification of Capsicum annuum L. and Capsicum frutescens L. in West Africa using morphological traits. In Notulae Botanicae Horti Agrobotanici Cluj-Napoc, vol. 47(1), p. 135-142.

OROBIYI, A., LOKO, L.Y., SANOUSSI, F., AGRÉ, A.P., KORIE, N., GBAGUIDI, A., ADJATIN, A., AGBANGLA, C., DANSI, A. 2018. Agro-morphological characterization of chili pepper landraces (Capsicum annuum L.) cultivated in Northern Benin. In Genet Resour Crop Evol, vol. 65, p. 555-569. https:// doi.org/10.1007/s10722-017-0553-X

PAPOUI, A.D.P., YOSIPOVITCH, G. 2010. Topical capsaicin. The fire of a "hot" medicine is reignited. In Expert Opin Pharmacoter, vol. 11(8), p. 1359-1371. https://doi.org/10.1517/14656566.2010 .481670

PRUTHI, J.S. 2003. Chemistry and quality control of Capsicum and Capsicum products. In DE, A.K., editor. Capsicum. The genus Capsicum. London and New York : Taylor \& Francis, p. 25-70.

RODRÍGUEZ-MATURINO, A. et al. 2011. Antioxidant activity and bioactive compounds of Chiltepin (Capsicum annuum var. glabriusculum) and Habanero (Capsicum chinense): A comparative study. In Journal of Medicinal Plants Research, vol. 6, p. 1758-1763. https://doi.org/10.5897/ IMPR11.1576

SALEH, B. K., OMER, A., TEWELDEMEDHIN, B. 2018. Medicinal uses and health benefits of chilli pepper (Capsicum spp.): a review. In Food Processing \& Technology, vol. 6, p. 325-328. https://doi. org/10.15406/mojfpt.2018.06.00183

SAROBO, Z.B. 2019. Profiling the diversity of morphological traits for future Malaysian breeding programme in Capsicum genetic resources. University Teknologi Malaysia : Thesis, $37 \mathrm{p}$.

SCALDAFERRO, M., BARBOZA, G.E., ACOSTA, M.C. 2018. Evolutionary history of the chilli pepper Capsicum baccatum L. (Solanaceae): domestication in South America and natural diversification in the Seasonally Dry Tropical Forests. In Biol J Linnean Soc., vol. 124, p. 466-478.

SHAHA, R.K., RAHMAN, S., ASRUL, A. 2013. Bioactive compounds in chilli peppers (Capsicum annuum L.) at various ripening (green, yellow and red) stages. In Annals of Biological Research, vol. 4, p. 27-34.

SHOTORBANI, N., JAMEI, R., R. 2013. Antioxidant activities of two sweet pepper Capsicum annuum L. varieties phenolic extracts and the effects of thermal treatment. In Avicenna Journal of Phytomedicine, vol. 3(1), p. 25-34.

STEHLÍKOVÁ, B. 1998. Základy bioštatistiky. [Fundamentals of biostatistics]. Učebné texty pre dištančné štúdium. Nitra: Ochrana biodiverzity. [In Slovak].

VINOGRADOVA, YU., GRYGORIEVA, O., VERGUN, O., BRINDZA, J. 2017. Morphological characteristics for fruits of Aronia Mitschurinii A.K. Skvortsov \& Maitul. In Potravinarstvo Slovak Journal of Food Sciences, vol. 11(1), p. 754-760. https://doi.org/10.5219/845

WAHUA, C., OKOLI, B.E., EDWIN-WOSU, N.L. 2014. Morphological, anatomical, cytological and phytochemical studies on Capsicum annuum Linn. (Solanaceae). In European Journal of Experimental Biology, vol. 4(1), p. 464-471.

ZHIGILA, D.A., ABDULRAHAMAN, A.A., KOLAWOLE, O.S., OLADELE, F.A. 2014. Fruit Morphology as Taxonomic Features in Five Varieties of Capsicum annuum L. Solanaceae. In Journal of Botany, Article ID 540868, 6 p. https://dx.doi.org/10.1155/2014/540868

ZOU, Y., MA, K., TIAN, M. 2015. Chemical composition and nutritive value of hot pepper seed (Capsicum annuum) grown in Northeast Region of China. In Food Science and Technology (Campinas), vol. 35, p. 659-663. http://dx.doi.org/10.1590/1678-457X.6803 